\begin{tabular}{|l|l|l||}
\hline \multicolumn{2}{|c|}{ PublisherInfo } \\
\hline \hline PublisherName & $:$ & BioMed Central \\
\hline \hline PublisherLocation & $:$ & London \\
\hline \hline PublisherImprintName & $:$ & BioMed Central \\
\hline \hline
\end{tabular}

\title{
Death by PARP
}

\begin{tabular}{|l|l|l||}
\hline \multicolumn{2}{|c|}{ ArticleInfo } \\
\hline \hline ArticleID & $:$ & 4532 \\
\hline \hline ArticleDOI & $:$ & $10.1186 /$ gb-spotlight-20020717-02 \\
\hline \hline ArticleCitationID & $:$ & spotlight-20020717-02 \\
\hline \hline ArticleSequenceNumber & $:$ & 198 \\
\hline \hline ArticleCategory & $:$ & Research news \\
\hline ArticleFirstPage & $:$ & 1 \\
\hline \hline ArticleLastPage & $:$ & 2 \\
\hline \hline & & RegistrationDate : 2002-7-17 \\
\hline ArticleHistory & $:$ & OnlineDate \\
\hline \hline ArticleCopyright & $:$ & BioMed Central Ltd2002-7-17 \\
\hline \hline ArticleGrants & $:$ & \\
\hline \hline ArticleContext & $:$ & 130593311 \\
\hline \hline
\end{tabular}




\section{Jonathan B Weitzman}

Email: jonathanweitzman@hotmail.com

PARP-1 (poly(ADP-ribose) polymerase-1) is a nuclear enzyme that is important for genome repair and DNA replication. PARP-1 also induces cell death in a number of physiological contexts. In the July 12 Science, Yu et al. describe a mechanism by which nuclear PARP-1 regulates a mitochondrial protein to induce apoptosis (Science 2002, 297:259-263). They studied fibroblasts generated from parp-1 knockout mice and examined the response to DNA-alkylating agents; they found that cells from the knockout mice failed to undergo apoptosis and lacked nuclear translocation of the mitochondrial flavoprotein apoptosis-inducing factor (AIF). Neutralizing anti-AIF antibodies blocked PARP-1-dependent cell death. Yu et al. propose a mechanism in which DNA damage induces PARP-1 activation leading to NAD+ consumption that is sensed by mitochondria and results in AIF translocation to the nucleus, nuclear condensation and death. This study thus provides a molecular link between the integrity of the nuclear genome and activation of mitochondrial killer proteins.

\section{References}

1. Molecular and biochemical features of poly (ADP-ribose) metabolism.

2. Science, [http://www.sciencemag.org]

3. Apoptosis-inducing factor (AIF): a ubiquitous mitochondrial oxidoreductase involved in apoptosis. 